\title{
PUNK MAKASSAR: SUBKULTUR YANG KREATIF
}

\author{
Israpil \\ Balai Penelitian dan Pengembangan Agama Makassar \\ J1. A.P. Pettarani No. 72 Makassar \\ e-mail: apillitbang@vahoo.com
}

\begin{abstract}
Abstrak
Penelitian ini bertujuan untuk memberikan gambaran terkait pola hidup Komunitas Punk di Kota Makassar. Penelitian ini menggunakan pendekatan deskriptif kualitatif jenis studi kasus dengan terlebih dahulu melakukan observasi untuk selanjutnya dilakukan wawancara mendalam sebagai pedoman penelusuran data. Penentuan informan dilakukan dengan teknik purposive, yaitu informan yang dianggap mengetahui tentang apa yang sedang diteliti. Hasil penelitian menunjukkan, bahwa Komunitas Punk di Kota Makassar timbul sebagai gerakan perlawanan anak muda akibat ketidakpuasan terhadap kekuasaan dan kebudayaan dominan, menentang bentuk represi atas kebebasan berekspresi yang dibuat oleh kaum kapitalis melalui kebijakan pemerintah. Penampilan, bahasa tutur, dan sifat eksklusif mereka di tengah-tengah masyarakat Kota Makassar dianggap sebagai sebuah penyimpangan sosial. Tapi di saat yang sama kehadiran komunitas ini di Kota Makassar sesungguhnya juga berimplikasi positif bagi generasi muda yang ditunjukkan melalui sikap kemandirian dalam berkreativitas dalam bentuk zine, bermusik,/as/n'on, dan usaha studio tato.
\end{abstract}

Kata Kunci: punk, kapitalisme, resitensi, subkultur

\begin{abstract}
Research aims to describe punk lifestyle in Makassar. With descriptive and qualitative approach, research conducted through observation and in depth interview. Informants selected purposively based on the knowledge and the experience they have on the subject of research. Result shows that community of punk in Makassar was born because of their disappointment and dissatisfaction to the dominant culture and power. They resist against repression on freedom of expression made by capitalist and exercised through government policy. Their lifestyle, language, and exclusivity in a mid of Makkassar community possibly regarded as social deviation. However, their existence shows positive lifestyle of young generation. They areindependent and creative. It can be seen in their product of zine, music, fashion and tattoos studio.
\end{abstract}

Keywords: Punk, capitalism, resistance, sub culture

\section{PENDA H U L U A N}

$\mathrm{K}$ ajian tentang komunitas Punk sudah banyak dilakukan oleh berbagai kalangan disipilin keilmuan. Akan tetapi, fenomena anak muda ini, tetap saja menarik untuk dikaji.

Penampilan Punkers (sebutan pengikut komunitas ini) sangat mudah dikenal karena berbeda dan sangat mencolok dari masyarakat kebanyakan. Gaya rambut Mohawk ala suku Indian (berdiri tegak lurus menyerupai paku yang menancap), dan dicat warna-warni. Bukan hanya itu, pierching atau tindik (lubang) di beberapa bagian tubuhnya seperti telinga, pelipis mata, bibir, hidung, pusar, maupun lidah. Lubang yang dibuat kemudian dihiasi dengan aksesoris pierching. Penampilan khas inipun masih dilengkapi dengan aksesoris lainnya seperti rantai sebesar jari di leher, celana jeans ketat, dompet dengan rantai panjang menjuntai, dan tentu saja tato yang menempel di sekujur tubuhnya.

Punk mulai masuk ke Makassar sekitar akhir 90-an. Masuknya gaya hidup Punk ke Makassar diawali pula oleh masuknya musik-musik beraliran Punk. Namun perkembangannya tidak sepesat di Jawa seperti di Bandung dan Yogyakarta. Punk di Makassar pada awalnya hanyalah sebuah komunitas kecil yang tidak terang-terangan menunjukkan gaya hidup Punk. Kemudian anak-anak muda mulai meniru gaya berpakaian dan mulai memahami 
ideologi dan akhirnya menjadikan Punk sebagai gaya hidupnya.

Pada perkembangannya, baik di negeri asalnya Inggris, dan Amerika, maupun di Indonesia, komunitas Punk telah mempunyai suatu subkultur tersendiri yang diakui masyarakat dan terkadang dianggap menyimpang. Punk juga telah semakin populer dengan timbulnya Punk sebagai suatu trend. Contohnya dalam dunia fashion. Gaya berpakaian Punk menjadi trend fashion masyarakat umum (Indaryanto, 2011:1).

Dominasi negara, norma masyarakat, norma keluarga, dan eksploitasi kapitalisme bagi komunitas Punk adalah bentuk pengekangan terhadap ekspresi dan aktualisasi diri. Hal inilah yang menjadi target pemberontakan yang kemudian tersimbolisasi ke dalam fashion, aliran musik, dan studio tato yang mereka kembangkan.

Seiring dengan modernisasi dan pembangunan yang pesat di Kota Makassar, eksploitasi kapitalis pun berlangsung massif. Inilah yang menjadi ladang subur bagi tumbuhnya Komunitas Punk di Makassar.

Sejak pertama muncul, keberadaan Punk di Makassar acapkali dianggap pelanggaran norma, pengacau, atau biang keributan. Tidak jarang di antara mereka diawasi oleh aparat keamanan lantaran dicurigai berpotensi kriminal.

Persepsi miring dan cenderung negatif ini jelas tak seluruhnya benar. Banyak anggota Punk yang bergabung karena di tempat inilah mereka bebas berkreasi, mendesain model baju yang berbeda dari gaya fashion yang lazim, mencipta musik dan lagu yang lain dari lagu-lagu komersil dan banyak lagi kreatifitas lainnya. Sebagaimana lazimnya Punk di tempat lainnya, Punk Makassar pun membuat dunianya sendiri, membangun budaya yang berbeda dengan budaya mainstream. Inilah dalam pandangan Barker sebagai subkultur. Kata kultur dalam subkultur menunjuk pada keseluruhan cara hidup atau sebuah peta makna yang memungkinkan dunia bisa dimengerti oleh anggota-anggotanya. Karena itu klaim bahwa mereka penyakit sosial, tidaklah selamanya benar.

Di sinilah kita harus memahami bagaimana kekuasaan tersebar di masyarakat, kelompok mana yang menentukan tentang sesuatu dan menggolonggolongkan kehidupan sosial ini. Saat ini, ideologi kapitalis-modernis dengan sebaran kuasanya di masyarakat telah meletakkan kondisi sosial, yang akan bermasalah jika menggugatnya.
Jika merujuk kategori pemerintah Makassar terhadap Punk yaitu sekitar 100 orang (Makassartv. co.id, diakses 3 Desember 2013), kesemuanya dianggap sebagai biagian dari anak jalanan, yang jumlahnya 990 orang. Hal ini dapat dimaklumi, karena komunitas Punk di Kota Makassar, menampakkan identitasnya ketika mereka berada di jalan. Namun tentu sajakategori ini tidak memahami posisi Punk sebagai satu subkultur. Komunitas Punk sesungguhnya adalah simbol perlawanan, kreativitas sekaligus kepedulian. Slogan mereka tentang "No Rule, No God, No Master" menjadi bagian ekspresi kultur mereka yang subversif atas kultur komodifikasi dan industrial kota yang kaku dan mengalienasi. Tapi apa mau dikata, keluar dari konstruk sosial kapitalisme-modernisme pastilah akan dipandang aneh, kelainan sosial, kegilaan, biang kekacauan dan pada akhirnya diletakkan dalam kerangkeng menakutkan patologi sosial. Tulisan ini mencoba membuktikan bahwa Punk Makassar adalah komunitas perlawanan yang kreatif. Mereka melawan budaya kapitalisme dan industrialisasi lewat produksi kebudayaan. (Kartono, 2009)

Berdasarkan latar belakang, maka permasalahan yang dibahas dalam penelitian ini adalah bagaimana bentuk perlawanan Komunitas Punk di Kota Makassar?. Tujuan penelitian ini adalah mengetahui bentuk gerakan perlawanan yang dilakukan Komunitas Punk di Kota Makassar melalui produksi kebudayaan.

\section{Tinjauan Pustaka}

Penelitian tentang Komunitas Punk telah banyak dilakukan oleh berbagai kalangan, seperti yang ditulis oleh Aris Prasetyo Indaryanto (2011) tentang Identifikasi Keterpaan dan Kontribusi Komunitas Punk pada Penyakit Masyarakat di Jakarta Selatan. Hasil penelitiannya terungkap bahwa Komunitas Punk yang ada di jalan-jalan wilayah Jakarta Selatan sangat rentan diterpa oleh penyakit-penyakit masyarakat seperti minuman keras, penyalahgunaan obat dan narkotika, seks bebas, dan pelacuran, serta tindakan kejahatan.

Tulisan lain adalah Ronaldi (2012), Komunitas Punk di Tana Toraja. Penelitian ini mengungkap Komunitas Punk di Tana Toraja memilih hidup di jalan bukan karena faktor ekonomi, namun juga karena mereka menikmati kondisi lingkungan di jalan.

Kedua tulisan tersebut pada umumnya menyoroti sisi negatif kehidupan Komunitas Punk yang terkesan menghabiskan waktu hidupnya hanya 
di jalan. Tulisan ini berbeda dengan hasil penelitian di atas. Tulisan ini tidak melihat Komunitas Punk dari sisi negatifnya saja tetapi dibalik itu, kehadiran mereka juga perlu diapresiasi secara positif dengan kreativitas yang mereka bangun dan kemudian mereka simbolkan sebagai suatu gerakan perlawanan.

\section{Subkultur}

Kata kultur dalam subkultur menunjuk pada keseluruhan cara hidup atau sebuah peta makna, yang memungkinkan dunia bisa dimengerti oleh anggota-anggotanya. Kata sub mengonotasikan kekhususan dan perbedaan dari kebudayaan dominan (mainstream). Thornton mengatakan bahwa subkultur bisa juga dilihat sebagai sebuah ruang di mana "kebudayaan yang menyimpang" menegosiasikan kembali posisinya atau justru merebut dan memenangkan ruang itu. Jadi subkultur kesamaan dengan deviasi, yakni ketidaksamaan (Hatib, 2006:31).

Djalaluddin Rahmat (Hatib, 2006:40), menyatakan bahwa deviasi itu bagaikan proses ketika kita masuk toilet. Hidung kita akan tersentak oleh bau yang tak sedap namun lama-kelamaan kita tidak merasakannya lagi karena mampu beradaptasi dengan keberadaan bau tersebut. Lama-kelamaan deviasi pun demikian, ia akan menjadi pemafhuman dalam masyarakat seiring dengan derasnya arus informasi dan globalisasi yang terjadi.

Subkultur tingkatannya sama dengan counter cultureyaitu merupakan bagian turunan dari culture. Counter culture merupakan suatu kebudayaan khusus yang oleh masyarakat dianggap sebagai sesuatu yang bertentangan dengan kebudayaan induknya atau nilai-nilai kaidah-kaidah yang dianut oleh warga masyarakat secara umum.

Kebudayaan Punk selalu bersifat kritis terhadap budaya dominan yang dibentuk sistem kapitalis. Konsekuensinya, kreasi dan perilaku simbolik Komunitas Punk dilihat sebagai bentuk perlawanan (Hardiyansyah, 2011).

\section{Metode Penelitian}

Dalam mengaji fenomena sosial Komunitas Punk, metode penelitian yang digunakan adalah penelitian deskriptif kualitatif untuk mengeksplor dan menggambarkan secara mendalam fenomena keberadaan komunitas Punk di Kota Makassar. Penelitian kualitatif dilakukan karena peneliti ingin mengeksplor fenomena-fenomena yang tidak dapat dikuantifikasi yang bersifat deskriptif seperti proses suatu langkah kerja, formula suatu resep, karakteristik suatu barang dan jasa, tata cara suatu budaya, dan lain sebagainya (Komariah, 2010:23).

Objek penelitian ini dilakukan pada kondisi yang alamiah (natural setting), berkembang apa adanya. Penelitian ini disebut juga sebagai metode etnografi, karena pada awalnya metode ini lebih banyak digunakan untuk penelitian antropologi budaya; disebut sebagai metode kualitatif, karena data yang terkumpul dan analisa lebih bersifat kualitatif (Sugiyono, 2011:1)

Fokus penelitian ini adalah komunitas Punk di Kota Makassar, terutama gerakan perlawanan yang tersimbolisasi dari kreativitas yang mereka kembangkan.

Dalam penelitian ini instrumen utama adalah peneliti sendiri dengan menggunakan beberapa alat bantu, yakni: pedoman observasi lapangan, pedoman wawancara/catatan lapangan, tape recorder, dan alat penunjang lainnya.

Pengumpulan data dilakukan dengan cara observasi partisipatif, dokumentasi dan wawancara mendalam. Observasi partisipatif digunakan dalam teknik kualitatif karena suatu objek hanya dapat diungkap datanya apabila peneliti menyaksikan secara langsung, mengungkap gerak-gerik, sikap, suasana keadaan obyekyang sedang diteliti. Maleong (2007:164) melengkapi definisi ini, bahwa observasi partisipan, adalah pengamatan berperan serta, "pada dasarnya berarti mengadakan pengamatan dan mendengarkan secermat mungkin sampai pada yang sekecil-kecilnya sekalipun". Kemudian wawancara dilakukan tidak terstruktur, mirip dengan percakapan informal.

Analisis data yang digunakan adalah analisis data kualitatif dengan menggunakan cara analisis data sambil mengumpulkan data (analysis in the field) dengan mengeksplorasi secara mendalam isi pernyataan yang diberikan oleh informan. Teknik ini dilakukan dengan pengorganisasian data, menguraikan data menjadi unit yang lebih kecil, melakukan sintesa di antara data, mencari pola-pola hubungan atau interaksi di antara data, menemukan aspek penting yang harus didalami, dan akhirnya menentukan apa saja yang perlu dilaporkan serta diinformasikan kepada masyarakat atau pembaca.

\section{PEMBAHAS A N}

Prakondisi Kemunculan Punk Makassar sebagai Gerakan Perlawanan

Pra kondisi sebagai pemicu gerakan perlawanan sosial komunitas Punk Makassar terhadap kekuasaan dominan dan kebudayaan dominan memiliki rangkaian penyebab yang 
cukup variatif. Setidaknya ada dua faktor penyebab terjadinya suatu gerakan perlawanan anak muda Punk di Makassar.

Pertama, dapat dilihat dari sejarah masa lalu, bahwa orang Makassar pada zaman penjajahan Belanda memang dikenal mempunyai peringai yang cukup keras menantang ketidaksewenangwenangan penjajah Belanda. Bahkan sampai sekarang, masyarakat Makassar sangat menantang ketidakadilan. Salah satu gerakan perlawanan masyarakat yang cukup menggemparkan Belanda yang dipimpin oleh I Tolok Daeng Magassing 1914. Gerakan ini muncul dari bawah sebagai ledakan keresahan sosial dalam masyarakat (Palallo, 2008:19). Pada permulaan abad ke-20, ketika wilayah tanah Makassar khususnya Sulawesi Selatan dikuasai pemerintah Hindia Belanda, terjadi tindakan perampokan yang menunjukkan kecenderungan sebagai gerakan penolakan terhadap dominasi kekuasaan pemerintah Hindia Belanda. Malahan perampokan oleh kelompok bangsawan dan pejabat pemerintah bumiputra . bentukan pemerintah Hindia Belanda. W.J. Coenen (Palallo, 2008:44) menyatakan bahwa gerakan perampokan yang terjadi merupakan gerakan perampokan yang bersifat politik. Pernyataan Coenen itu mengisyaratkan bahwa tindakan perampokan itu merupakan suatu cara yang ditempuh untuk melakukan gerakan. Sehingga gerakan itu dapat dikatakan gerakan per-bandit-an sosial.

Dalam konteks kehadiran Komunitas Punk di Kota Makassar, tidaklain adalah gerakan perlawanan terhadap ketidakadilan, antipenindasan terutama yang dilakukan penguasa terhadap kaum marginal. Aplikasi gerakan perlawanan yang mereka lakukan tidak dilakukan dengan cara kekuatan fisik seperti mengangkat senjata tapi melalui pikiran-pikiran dan simbol-simbol yang mereka ciptakan.

Ical (41 tahun), seorang punker yang sejak di SMA bergabung di Komunitas Punk dan memiliki usaha distro ini, mengatakan, "Kami tetap protes terhadap setiap kebijakan yang dibuat oleh penguasa, yang kami anggap tidak memihak kepada kaum marginal termasuk kami. Seperti yang terjadi pada teman-teman kami di Aceh, digunduli secara ramai-ramai oleh aparat keamanan" (Wawancara, 21/5/2013).

Kedua, Punk Makassar tidak setuju dengan dominasi kekuasaan dan budaya dominan, terutama pihak kapitalis. Dimana pemerintah hanya ingin mengakomodir kemauan dari atas terutama pihak kapitalis. Komunitas Punk Makassar mendefinisikan kapitalis sebagai sistem ekonomi yang tidak demokratis, sumber daya dimiliki secara privat dan semua orang berlomba-lomba berebut kekuasaan atasnya, nyaris semua sumber daya berujung pada kekuasaan di tangan segelintir orang saja. Seperti dikatakan informan anak Punk Makassar yang fasih berbahasa Inggris dan penulis zine. yaitu Ady (23 tahun), bahwa kapitalis hanya memusatkan dan memaksakan arti hidup setiap orang pada apa yang mampu dimiliki, bukan kepada apayang dilakukan. Dengan begitu, tujuan hidupnya adalah menumpuk harta sebanyak-banyaknya dan meraih status sosial (Wawancara, 23/5/2013).

Selain itu, prinsip aplikasi budaya yang dijalankan Punk tidak sejalan dengan konsep budaya dominan yang cenderung teratur, rapi, dan monoton sifatnya. Demikian pula sering adanya pertentangan remaja Punk melawan budaya orangtua dan masyarakat lainnya. Mereka ingin bebas sebebas-bebasnya tanpa ada aturan yang mengikatnya.

Merujuk kepada konsep ideologi yang dijabarkan Antonio Gramsci, kebudayaan sangat terikat dengan ideologi. Hal ini karena ideologi suatu kelompok dihasilkan dan dihasilkan kembali melalui praktik-praktik yang dilakukannya (Agger, 2003: 249). Makna, tanda-tanda, dan nilai-nilai teraplikasi dalam wacana kebudayaan kehidupan sosial.

Ideologi merupakan konsep yang mengikat pelaku kebudayaan. Konsep tersebut diturunkan dalam bentuk aturan-aturan. Aturan-aturan tersebut pada akhirnya diaplikasikan melalui perilaku pelaku kebudayaan. Sejalan dengan itu, Williams (Hibdige) menyebutnya sebagai cara hidup tertentu yang meng-ekspresikan makna dan nilai tertentu, bukan hanya di dalam seni dan pembelajaran, tapi juga di dalam institusi dan perilaku sehari-hari (Hibdige, 1999: 19).

Berdasarkan observasi, keberadaan Komunitas Punk di Makassar menyebar hampir di setiap sudut kota Makassar, terdapat 20 titik komunitas Punk, seperti: Pepabri Sudiang, BTN Mangga Tiga, BTP Chaos, BTN Hamzih, Antang, Paropo Tello, Barawajah, Bambapuang, Kandea, Cendrawasih, Andalas, Barukang Rappokalling, Teuku Umar, Rajawali, J1. Muhammad Tahir, Kijang, Baji Gau, Sungai Saddang, Workshop UNHAS dan di Taman Indosat sekitar Fort Rotterdam perapatan J1. Penghibur Makassar. Ini membuktikan bahwa 
Komunitas Punk di Kota Makassar masih tetap eksis sebagai ideologi anak muda dalam melakukan gerakan perlawanan dan diwujudkan melalui sikap ketidaksukaan mereka terhadap penguasa dan kapitalis. Menurut leal (41 tahun), selama masih ada penindasan, Komunitas Punk tetap ada.

Punk Makassar tidak lagi percaya kepada pemerintah terutama kapitalis. Menurut mereka, kapitalis telah melakukan penindasan terhadap pedagang-pedagang kecil melalui kebijakankebijakan yang dibuat oleh pemerintah.

Togaf (20 tahun) seorang punkers yang membuka usaha studio tato, mengatakan "Kebijakan yang dibuat pemerintah bersifat diskriminatif, yang hanya mementingkan kaum dominan dan kaum pemilik modal saja dalam hal ini kapitalis. Sedangkan pihak lain seperti pedagang-pedagang kecil tidak diberi ruang dan tempat untuk berusaha, sehingga mereka berdagang berdesakan di pinggir jalan raya. Buktinya yang dilihat, kelompokkelompok dominan yang berduit itu merasa nyaman dalam melakukan usahanya. Sedangkan pada pihak lain seperti pedagang kaki lima tidak terlalu diperhatikan, bahkan terkadang ada penggusuran di sana sini. Kemudian, dalam hal pekerjaan, orang bertato (Punk) tidak bisa diterima bekerja di instansi-instansi pemerintah" (Wawancara, 23/5/2013).

Meskipun begitu, Komunitas Punk di Kota Makassar tetap saja eksis sampai sekarang karena sikap solidaritas dan kemandirian yang dikenal do it yourself yang masih melekat pada setiap anak Punk. Hal ini diperkuat oleh pernyataan informan Ady (23 tahun) punkers Makassar, penulis zine yang fasih berbahasa Inggris itu, mengatakan, komunitas Punk masih ada di Kota Makassar ini karena adanya sikap kemandirian masih melekat pada diri setiap anak Punk.

Pendapat di atas sejalan dengan Hebdige, bahwa sikap kemandirian hanyalah pertentangan remaja punkers melawan budaya orang tua mereka. Remaja-remaja tersebut mengalami masa-masa individualisme yang menginginkan kebebasan (Hebdige, 1999:144). Selanjutnya, sikap kemandirian dibuat untuk mencerminkan, mengekspresikan, dan menyuarakan segi-segi kehidupan kelompok. Stuart Hall (Hebdige, 1999:228).

Kemandirian merupakan sikap dasar dari etika do it yourself, yang berarti tidak tergantung kepada orang lain. Seorang punkers dituntut untuk berusaha mandiri dalam melakukan segala sesuatu. Namun, dalam melakukannya bukan berarti bersikap individualistis. Mereka menyadari bahwa tidak semua hal dapat dilakukan seorang diri. Kemandirian merupakan sikap seorang punkers untuk berusaha sendiri terlebih dahulu. Kalaupun ternyata tidak mampu, baru meminta bantuan kepada punkers lain maupun pihak lain yang memiliki kesamaan ide.

Perlawanan punkers Makassar terhadap kapitalisme, melalui sikap kemandirian dapat dilakukan dengan: Pertama, berusaha memberikan jarak dengan kapitalisme. Punkers Makassar berusaha tidak terjebak dengan ketergantungan dalam memenuhi kebutuhan hidup kepada kapitalisme seperti kebanyakan orang saat ini. Seperti yang diungkapkan informan Ady (23 tahun) bahwa Punk menolak mentah-mentah kapitalisme, tapi bukan berarti menolak untuk kaya. Seorang Punker apabila ia kaya, berusaha tidak komsumtif dan menghilangkan sifat hedo, kekayaannya hanya dipergunakan untuk membantu orangorang tertindas di sekelilingnya. Kedua, mereka menciptakan kebebasan dalam mengembangkan kreativitas yang dimiliki, seperti yang dilakukan oleh informan leal (41 tahun) yang mendirikan usaha distro, dan Togaf (20 tahun) yang membuka bisnis studio tato.

Tindakan kapitalis memenuhi segala kebutuhan masyarakat dilakukan dengan keseragaman yang memaksa atau, seperti yang ditulis Adorno dan Horkheimer, 'sesuatu yang disediakan bagi semua orang sehingga tak seorang pun bisa lari darinya (Hardiyansyah, 2011:33). Hal demikian menjadikan masyarakat menjadi terkekang dan tidak memiliki. kreativitas dalam melakukan sesuatu karena telah dibatasi kapitalis.

Punkers Makassar melalui sikap kemandirian berusaha untuk bebas dalam mengembangkan kreativitasnya. Salah satunya melalui usaha distro (bermula dari gerobak), musik, peraching, dan tato. Lewat musik misalnya, mereka berusaha 'melawan industri musik kapitalis. Industri musik kapitalis menyeragamkan dan memaksa masyarakat dengan menyajikan musik-musikbertemapersonal dan cinta pribadi. Dengan kemandirian Punkers Makassar menciptakan karya bertema lain, mendapat tempat hati remaja Makassar, dan memberikan pilihan kepada masyarakat dengan sajian musik yang berbeda-beda dan melawan dominasi kapitalis yang terus memaksa masyarakat.

Setidaknya, Punk Makassar tetap eksis sampai sekarang ini, karena jiwa kebersamaan yang mereka bangun. seperti hak berpendapat, persamaan ras, 
persamaan gender, dan persamaan memperoleh pengetahuan.

Komunitas Punk juga tidak mengenal bentukbentuk hirarki dan struktur yang selama ini masih dianut oleh masyarakat dominan dalam kehidupan sosial antara lain senior dan junior, pemodal dan pekerja, majikan dan pembantu, atasan dan bawahan dan sebagainya. Di Komunitas Punk semuanya sama tidak ada pimpinan dan yang dipimpin.

Gerakan perlawanan komunitas Punk Makassar tidak berangkat dari ruang kosong, tapi berangkat dari dialektika dan melalui perenungan dan sensitivitas sosial yang ada pada mereka.

\section{Perlawanan Kreatif Komunitas Punk Makassar}

Gerakan perlawanan komunitas Punk Makassar merupakan gerakan perlawanan anak muda yang berlandaskan dari keyakinan we can do it ourselves. Mulai dari gaya hidup sampai kepada pola pikir yang diimplementasikan ke dalam bentuk fanzine, fashion, musik, tato, dan tindik.

\section{Fanzine (Zine)}

Zine merupakan kependekan dari fanzine (fan magazine). Zine diciptakan dan muncul sebagai respon atau perlawanan Punk dari media massa mainstream. Sebab itu, biasanya zine berisi hal-hal yang bersifat menggugah, atau provokatif (tentu provokatif dapat dimaknai berbeda-beda, tergantung pada sudut pandangnya: bisa 'positif atau 'negatif'). Ketika media konvensional tidak lagi memadai bagi suara-suara (hasrat) komunitas Punk, bagi hasrat informasi yang lebih spesifik, tataletak dan corak yang khas lagi kreatif (dari sisi desain), maka zine adalah jawaban (representasi atau simbol) bagi individu maupun Komunitas Punk.

Sebagai media alternatif, Stephen Duncumbe dalam Notes From The Underground sebagaimana dikutip Vantiani, menjelaskan bahwa ciri unik zine adalah media yang ditangani secara non-komersial, non-profesional (amatir), disirkulasikan secara 'underground' kadang acak, editor (zinesterkreator zine) anonim sebab kadang nama menjadi tidak penting kecuali isi, bahkan kadang sebuah zine tidak mencantumkan alamat di mana zine ini dibuat (Vantiani, 2010:1) sehingga respon atas zine kadang tidak sampai ke zinesters. Menurut informan Ady (23), bahwa editor (zinesters), atau pengedar utama dari suatu zine, merupakan kontributor terbesar dari zine-nya, namun dia biasanya juga akan mendapatkannya dari teman atau sesama
Punk yang ada di seluruh Indonesia. Isi zine juga bisa merupakan bajakan atau 'pinjaman' dari zine lainnya atau media mainstream sekalipun, bahkan kadang diambil begitu saja tanpa ijin penulisnya (menyiratkan perlawanan terhadap penolakan hak cipta/copy right).

Jaques Derrida (Vantiani, 2010: 2) misalnya mengatakan, kultur menulis membuat orang tidak terjebak (gampang percaya) pada 'kebenaran' yang terlontar dari ucapan atau ujaran, sebab tidak jarang bahasa tutur dianggap paling representatif untuk menyampaikan sesuatu 'kebenaran' (fonosentrisme). Menurutnya bahasa tutur justru kerap menelikung (dari pemaknaan denotatif) kita atas maksud dalam kata-kata yang tersuarakan lewat mulut.

Dalam konteks gagasan Derrida ini, tulisan menjadi 'istimewa', dan dengan demikian zine adalah salah satu media interaksi antarsubyek dalam mendialogkan pikiran melalui tulisan, sehingga tercipta iklim yang produktif. Zine dihidupi oleh kaum muda, (biasanya) di kota, dan ia sangat dinamis, sehingga zine ini penting dalam makna ia merupakan salah satu sarana mereproduksi gagasan kreatif, berargumen, dan mereproduksi respon secara kritis atas ide-ide awam yang dipersoalkan.

Di Komunitas Punk Makassar, banyak didapati majalah atau zine yang beredar terutama di kalangannya sendiri antara lain: Nyenyak, Ibu Pertiwi, tipis\#2 fanzine, ladang protes zine, sapi betina, Born to Die, Bullshit, Fuck Police. Isi dan redaksinya didominasi dalam bentuk protes, cacian, kegaulan, perasaan, uneg-uneg dan sebagainya.

\section{Fashion}

Selain di fanzine, komunitas Punk Makassar juga bergerak di bidang fashion. Fashion menjadi bagian yang tidak dapat dilepaskan dari penampilan dan gaya keseharian mereka. Benda-benda seperti baju dan aksesoris yang dikenakan bukanlah sekadar penutup tubuh dan hiasan. Lebih dari itu juga menjadi sebuah alat komunikasi untuk menyampaikan identitas pribadi atau kelompok.

Menurut Simmel, dua kecenderungan sosial yang penting dalam membentuk fashion. Bila salah satu kecenderungan itu hilang maka fashion tak akan terbentuk. Pertama, adalah kebutuhan untuk menyatu dan yang kedua adalah kebutuhan untuk terisolasi (Ibrahim, 2007:243).

Dengan fashion, mereka memberontak terhadap kaum borjuis yang membanggakan diri dengan fashion dari bentuk kemewahan. Setiap 
anggota komunitas Punk akrab dengan fashion dan aksesoris dalam kehidupan mereka yang mempunyai ciri tersendiri.

Dalam atribut Punk, sering dilihat dari pakaian (baju, celana, dan jaket kulit), tato, model rambut dan sepatu. Model baju dan celana yang lusuh identik dengan komunitas ini walaupun masih ada komunitas Punk lainnya yang berpakaian lebih keren.

Awalnya, mereka hanya membuat pakaian untuk mereka pakai sehari-hari. Seiring dengan berjalannya waktu, mereka membuat dengan jumlah yang lebih banyak dan juga desain yang lebih variatif. Wadah untuk pakaian yang diproduksi sendiri oleh anak-anak Punk Makassar sendiri biasa disebut distro. Awal perkembangan usaha distro di kalangan Punk Makassar bermula dari membuat gerobak (etalase jualan yang terbuat dari kayu memakai roda). Dengan menggunakan gerobak mereka gampang lari ketika ada penertiban dari aparat.

Gerobak sebagai tempat mereka menjual bajubaju kaos yang sudah disablon dan dimodifikasi. Usahanya ini pun mampu bersaing dengan produkproduk terkenal yang sudah akrab dengan remaja Makassar. Tidak hanya menjual pakaian, banyak aksesoris-aksesoris buatan anak-anak Punk juga yang dijual dan dijadikan senjata untuk publikasi band-band Punk Makassar yang sudah mempunyai album. Dari usaha-usaha dan kreativitasnya itu, sehingga mereka tetap eksis sampai sekarang dan sudah mulai membangun dan membuka counter yang lebih permanen.

Punkers Makassar dengan masyarakat terutama generasi mudanya telah terjalin pola interaksi simbiosis mutualisme. Jadi, remaja Makassar dikatakan tidak gaul apabila belum belanja pakaian di distro.

Dari sekian banyak distro bentukan anak Punk di Makassar, Distro Rock and Roll72 di Jl. Perintis Kemerdekaan yang masih tetap konsisten memegang prinsip mereka yaitu tidak tergantung kepada kaum kapitalis. Di tempat inilah mereka mengolah kreativitas dengan memodifikasi baju kaos dengan cara: menyablon sendiri kaos mereka, biasanya terlebih dahulu membeli kaos polos untuk kemudian disablon berupa gambar-gambar band Punk ataupun tulisan-tulisan kritis dan tema-tema sosial. Kemudian, cara lain adalah merobek-robek beberapa bagian baju sampai terlihat sangat berbeda dengan bentuk baju aslinya, ketika dibeli pertama kali lalu menambahkan aksesori pada kaos seperti peniti, emblem, pin, dan lain-lain agar terlihat berbeda sehingga membentuk kelainan.

Dalam hal pemilihan warna, hitam merupakan warna dominan yang sering digunakan. Menurut mereka warna hitam merupakan simbol keberanian untuk tidak mau ditindas. Secara psikologis, warna hitam merupakan konfrontasi dan melanggar aturan.

Selain itu, bentuk kreasi lain yang sangat ditonjolkan dalam fashion komunitas Punk Makassar adalah: Jaket. Seperti halnya kaos, jaket kulit berwarna hitam merupakan andalan Punkers yang telah mengalami modifikasi yaitu dengan menempelkan beberapa emblem pada beberapa bagian menambahkan aksesori; Celana. Celana atau jeans yang dipakai Punkers lazim disebut celana street. Celana street adalah celana panjang berbahan jeans yang menyempit di bagian bawah. Saat ini, celana street trend di kalangan remaja dengan sebutan celana pensil. Modifikasi celana dilakukan dengan menyobek pada beberapa bagian dan atau menambahkan aksesori; Sepatu. Ada dua jenis sepatu yang digunakan Punkers, yaitu sepatu kain dan boot. Mereka yang digunakan biasanya adalah converse untuk sepatu kain dan Doctor Marten untuk boot. Sepatu kain pertama kali digunakan band Punk Ramones yang merupakan bagian dari penentangan fashion.

\section{Musik}

Istilah Punk sendiri pertama kali muncul dalam jurnalisme musik pada tahun 1970. Tepatnya saat Nick Tosches menulis sebuah esai berjudul The Punk Muse: The True Story of Protopathic Spiff Including the Lowdown on the Trouble-Making Five-Percent of America's Youth di Majalah Fusion Tulisan Tosches menjelaskan bahwa sebuah aliran musik baru di Amerika Serikat yang dimainkan sekelompok anak muda, yang memiliki visi ke depan tentang musik dan gaya hidup. (Majalah Hai edisi 8-14 Agustus 2005/Th.XXIX No. 22).

Band-band besar beraliran Punk yang melegenda di dunia musik sebut saja Sex Pistols, The Clash, The Ramones, The Exploited. Di Jakarta sendiri ada Marjinal, di Bali Superman is Dead, Sex Punk di Makassar, dan masih banyak lagi. Walaupun mereka semua berada di label indie namun karyakarya mereka tidak kalah hebat dengan bandband yang suka tampil di televisi. Ketika musikmusik lain menyuarakan lagu-lagu bertema cinta, perselingkuhan, dan lagu-lagu pop. 
Komunitas Punk di Makassar berkembang sebagai aliran musik. Dengan bermusik bisa dijadikan media kritik terhadap politik yang terartikulasi dan penolakan dari budaya dominan. Lewat bermusik, diciptakanlah lagu-lagu yang selalu menyuarakan suara kaum minoritas atas hak-hak mereka yang selalu tertindas. Untuk mengekpresikan semangat perjuangan yang mereka lakukan lewat lagu, biasanya musik Punk lebih cenderung memakai tempo cepat dan irama yang keras. Semangat patriotisme mereka selalu menggebu-gebu, ditambah lagi dengan jiwa persaudaraan mereka yang kuat.

Selain itu, musik digunakan sebagai alat untuk memberdayakan dirinya, untuk mencari makan, dan dengan bermain musik juga menjadi alat untuk membangun solidaritas. Menariknya di Komunitas Punk Makassar jarang sekali didapati anak-anak Punk yang mengamen di jalan-jalan. Kalaupun itu ada itu hanya sekadar mencari tambahan dana untuk kegiatan konser mereka. Seperti dituturkan oleh leal (41), bahwa "Kami pantang mengemis hanya untuk sesuap nasi".

Lagu-lagu yang mereka ciptakan, sengaja diciptakan berbeda dengan liriknya menggunakan kata-kata tidak sesuai dengan adat kesopanan dalam bertutur di dalam masyarakat Kota Makassar. Misalnya di antara lagunya dengan lirik fuck your self and die, aparat keparat, tailaso kabbulamma, sundala, kongkong (bah\&sa Makassar: artinya kurang lebih kurang ajar, anjing) yang dipopulerkan salah satu Band Punk Makassar yaitu Geto Box.

Saussure (Barker, 2004:70) berpendapat bahwa bahasa tidak mencerminkan realitas preexistent dan realitas eksternal dari sejumlah objek independen, namun ia menkonstruksi makna dari dalam dirinya melalui serangkaian perbedaan konseptual dan suara. Terbukti banyak band Punk Makassar yang mampu mendapat tempat di hati remaja Makassar. Sebut saja seperti Geto Box, The Hot Dogs, Puting Beliung, Sex Punk, Inviraw, Ollie Over, Game Over, Mutant, Pemuda Garis Depan, Anak Nabi, Pop is Dead, Skandal 14, The Hendrix, The Hidrasi, dan Kerclinek.

\section{Tato dan Pierching}

Dunia tato dan Pierching (tindik) identik dengan Komunitas Punk. Tato dan tindik dipahami sebagai dunia ekspresi kaum muda yang merepresentasikan gejolak ketidakberesan keadaan sekitar mulai dari materialism yang mengembang, korupsi yang menggurita hingga penyebab sepele seperti patah hati. Dengan kata lain, masyarakat (kaum muda) seakan tengah menentang sistem kemapanan sebagai rasa ketidakpercayaan. Pada sisi lain, mereka mencari nilai ideal yang dapat dijadikan pedoman dan kepercayaan.

Di dalam konsepsinya, Peter L. Berger (1991), merumuskan konsep proses dialektika fundamental dari sebuah masyarakat yang terdiri dari eksternalisasi, objektivikasi, dan internalisasi (Hatib, 2006).

Proses eksternalisasi adalah sebuah proses pengekspresian, pelepasan segala uneg-uneg secara berkelanjutan di dalam lingkup sosial budaya, yang berupa fisik dan psikis. Tindakan pentatoan dan tindik kaum Punk dapat dianggap sebagai proses mencari pencerahan sebagai reaksi atas hilangnya dunia spritualisme.

Proses objektivikasi adalah keadaan realitas atau praksis yang terjadi di lapangan, individuindividu bertato maupun bertindik mencoba untuk beradaptasi dengan kultur masyarakat sekitar yang notabene berbeda dengan mereka. Kondisi tersebut mau tidak mau menyebabkan lahirnya budaya baru dengan budaya asal, tak jarang terjadi pertentangan di kalangan masyarakat. Objektivikasi terkadang juga diartikan sebagai proses di mana manusia yang dieksternalisasikan tersebut mempunyai sifat objektif. Hal ini senanda dengan pandangan Berger \& Luckmann, realitas dikonstruksi melalui proses eksternalisasi, objektivikasi dan internalisasi (Bungin, 2011:16).

Bagi Komunitas Punk Makassar, tato dan tindik dianggap bersifat atraktif, dinamis, sesuai dengan jiwa muda mereka yang penuh semangat, ide kreativitas yang seakan semakin meledakledak ketika melihat suatu tatanan sosial kultural masyarakat yang terasa mengikat kebebasan dan terasa monoton. Bisa dikatakan remaja Punk selama ini memang terbentuk dalam sebuah eksistensi ambivalen, yang menempatkan mereka pada nilai-nilai paradoksal (perlawanan) kebudayaan antara orang tua sekaligus perlawanannya dengan kebudayaan dominan yang menjadi kesepakatan umum.

Komunitas Punk menganggap bahwa tato dan tindik dapat dianggap sebagai usaha untuk memenangkan ruang kultural dalam melawan kebudayaan yang dianut orang tua dan kebudayaan dominan yang berlaku umum di masyarakat. Kini tampaknya konsekuensi dari lahirnya budaya tanding, tato yang merebak di kalangan anak muda - dalam melawan segala sesuatu yang mapan - 
mendapat dukungan dari berbagai kalangan.

Seperti penuturan Togaf (20), seorang Punker yang membuka usaha studio tato di kawasan Muhammad Tahir mengatakan, "Secara pribadi tato adalah bentuk kepuasan diri dan beban serta pikiran terasa plong, tato juga menunjukkan bahwa saya seorang yang pemberani, tidak mudah untuk ditindas" (Wawancara, 23/5/2013). Dalam analisis budaya yang diungkapkan oleh Raymond Williams sering disebut "struktur perasaan" (Hatib, 2006:11). Nilai-nilai yang dianut oleh individu dalam masyarakat dapat terbaca melalui mode pakaian dan style tubuh.

\section{PENUT UP}

Kehadiran Punk di Makassar sesungguhnya adalah bentuk pertentangan anak muda akibat ketidakpuasan terhadap sistem pemerintahan terutama kapitalis, sistem kebudayaan, pengkotakkotakan sosial, penindasan di mana-mana, semakin lebarnya jurang pemisah antara masyarakat yang kaya dengan masyarakat yang miskin, menentang bentuk represi atas kebebasan berekspresi. Terutama sangat menentang sistem kapitalis, menurut mereka kapitalis melalui kebijakan-kebijakan yang dibuat pemerintah, di mana hanya menciptakan kelompokkelompok dominan yang memperkaya diri tanpa mau peduli dengan sesama.

Kemampuan Komunitas Punk di Makassar untuk mempertahankan diri dari berbagai stigmatisasi negatif dengan menunjukkan identitasnya, bahwa mereka juga memiliki kreativitas dan kecerdasan. Ini bisa dilihat dari cara mereka mengkritik kekuasaan dan budaya dominan dengan caranya sendiri. Media kritik terartikulasi dalam aktivitas keseharian dan kebiasaan-kebiasaan mereka yang disimbolkan melalui tulisan di media fanzine (zine), dengan usaha distro dan usaha tato yang mereka kembangkan, lewat fashion dan musik yang mereka ciptakan.

Sebagai komunitas yang terpinggirkan dari nalar dominan, tentu saja stigma negatif terhadap komunitas Punk Makassar tidak bisa dihindari. Masyarakat awam di Kota Makassar memandang Punk, seperti kelompok anak-anak nakal, musik rock, identik dengan rambut Mohawk dan lumrah dengan hal-hal buruk seperti kebiasaan-kebiasaan meminum-minuman alkohol, narkoba, eksentrik, tato dan tindik.

Namun apa yng ditunjukkan Komunitas Punk di Makassar seperti yang digambarkan di muka seharusnya membuka mata kita, tidak semua aktivitasnya menyentuh pada sisi negatif, banyak juga sisi positifnya perlu diapresiasi. Kita dapat melihat itu dalam cerminan kemandirian Komunitas Punk, misalnya dalam hal musik dan membuat zine. Menjamurnya distro-distro di Makassar adalah contohnya. Distro ini bukan serta merta muncul begitu saja, akan tetapi distro-distro di Makassar muncul karena dipelopori oleh keberadaan anakanak dari Komunitas Punk. Di tengah pandangan miring, punk Makassar telah mengembangkan ekonomi kreatif. Mereka memang berbeda dengan mainstream, namun perbedaan itu tak selamanya mewujud dalam bentuk yang negatif.

\section{Ucapan Terima Kasih}

Terima kasih penulis haturkan kepada pihakpihak informan terutama dari Komunitas Punk Makssar yang bersedia memberikan informasi terkait data yang diperlukan oleh peneliti dan kepada tim redaksi Jurnal Al-Qalam yang memasukan tulisan ini.

\section{DAFTAR PUSTAKA}

Agger, Ben. 2012. Teori Sosial Kritis: Kritik, Penerapan dan Implikasinya. Terjemahan oleh Nurhadi. Yogyakarta: Kreasi Wacana Offset.

Antikemapanan Sepanjang Jaman. Majalah Hai edisi 8-14 Agustus 2005/Th.XXIX No. 22.

Barker, Chris. 2004. Cultural Studies Teori dan Praktik. Terjemahan oleh Nurhadi. Yogyakarta: Kreasi Kecana.

Bungin, Burhan. 2001. Metodologi Penelitian Kualitatif. Jakata : Rajagrafmdo Persada.

Hardiyansyah, Ridwan. 2011. Sedikit Cerita Punk dari Bandar Lampung. Yogyakarta: Indie Book Corner.

Hatib, Abdul Kadir.2006. Tato. Yogyakarta: LkiS.

Hibdige, Dick. 1979. Asal-Usul dan Ideologi Subkultur Punk. Terjemahan oleh Wijaya, Ari. 1999. Yogyakarta: Penerbit Buku Baik.

Ibrahim, Idy Subandi. 2007. Budaya Populer Sebagai Komunikasi. Jogjakarta: Talasutra.

Indaryanto, Aris Prasetyo. 2011. 'Identifikasi Keterpaan dan Kontribusi Komunitas Punk pada Penyakit Masyarakat di Jakarta Selatan. Tesis. Jakarta: Tidak diterbitkan.Universitas Indonesia.

Kartono, Kartini. 2009. Patologi Sosial. Jakarta: Rajawali Pers. 
Komariah Aan, Satori Jama'an.2010. Metodologi Penelitian Kualitatif. Bandung: Alfabeta.

Makassartv.co.id. 21 Desember 2013. Demo Solidaritas Punk Makassar Kecam Penggundulan Di Aceh (Online). Diakses Tanggal 3 Desember 2013

Moleong J, Lexi. 2010. Metode Penelitian Kuantitatif. Edisi Revisi. Bandung: PT. Remaja Rosdakarya.

News detik.com. 19 Desember 2011. Penggundul rame-rame Komunitas Punk di Aceh. (Online). Diakses Tanggal 3 Desember 2013.

Palallo, M. Natsir. 2008. Bandit Sosial di Makassar:
Jejak Perlawanan I Tolok Dg. Magassing. Makassar: Rayhan Intermedia.

Ronaldi. 2012. Komunitas Punk: Studi kasus di Kelurahan Bombangan Kecamatan Makale Kabupaten Tana Toraja. Skripsi. Makassar: Tidak diterbitkan. Universitas Hasanuddin.

Sugiyono. 2011. Metode Penelitian Kombinasi (Mixed Methods). Bandung: Alfabeta.

Vantiani, Ika. 2010. "Zine, media tanpa mesti yang mesti dimaksimalkan lagi," makalah workshop Penulisan Kritik Seni Rupa, @ruangrupa, Jakarta 17 Juni 2010. 